\title{
Mathematical models for Isoptera (Insecta) mound growth
}

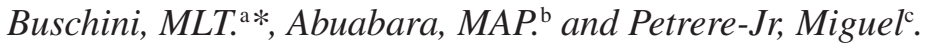 \\ aDepartamento de Biologia, Universidade Estadual do Centro-Oeste - UNICENTRO, \\ Rua Presidente Zacarias, 875, CEP 85010-990, Guarapuava, PR, Brazil \\ bDepartamento de Matemática da Universidade Estadual Paulista - UNESP, \\ CP 199, CEP 13506-900, Rio Claro, SP, Brazil \\ 'Departamento de Ecologia, Universidade Estadual Paulista - UNESP, \\ CP 199, CEP 13506-900, Rio Claro, SP, Brazil \\ *e-mail: isatunes@yahoo.com.br \\ Received December 18, 2006 - Accepted April 26, 2007 - Distributed August 31, 2008
}

(With 4 figures)

\begin{abstract}
In this research we proposed two mathematical models for Isoptera mound growth derived from the Von Bertalanffy growth curve, one appropriated for Nasutitermes coxipoensis, and a more general formulation. The mean height and the mean diameter of ten small colonies were measured each month for twelve months, from April, 1995 to April, 1996. Through these data, the monthly volumes were calculated for each of them. Then the growth in height and in volume was estimated and the models proposed.
\end{abstract}

Keywords: Nasutitermes coxipoensis, Isoptera, Insecta, mound growth.

\section{Modelos matemáticos para crescimento dos ninhos de Isoptera (Insecta)}

\section{Resumo}

Nessa pesquisa, propusemos dois modelos matemáticos derivados da curva de Von Bertalanffy para o crescimento dos ninhos de Isoptera; um específico para Nasutitermes coxipoensis; e outro mais geral. A altura média e o diâmetro médio de dez colônias pequenas foram medidas a cada mês, de abril de 1995 a abril de 1996. Através desses dados, foi calculado o volume mensal de cada colônia. Posteriormente os crescimentos em altura e volume foram estimados e os modelos propostos.

Palavras-chave: Nasutiternes coxipoensis, Isoptera, Insecta, crescimento de ninhos.

\section{Introduction}

All termites are social insects and live in communities, large or small, within the limits of a nest-system. The nest and associated structures, such as mounds, subterranean galleries and covered runways, comprise a closed system largely isolated from the external environment but allowing for the egress of foraging parties and flight of alates (Lee and Wood, 1971). In this system, within which the micro-climate can be controlled within certain limits, food can be stored, and they obtain some protection from natural enemies (Lee and Wood, 1971; Banerjee, 1975). The nest-system of these insects is not a static structure and is enlarged as the colony grows (Noirot, 1970).

Three recognisable developmental phases exist in termite societies. The first corresponds to a juvenile phase, during which there is just differentiation of the neuter castes. Soon after, the colony passes to the mature or adult phase, period in which the winged reproductives are produced. Finally, a phase of senescence occurs, when there is a decline in the nest population (Noirot, 1969). Collins (1981) deduced that the populations in the nests of Macrotermes bellicosus Smeathman 1781 increase exponentially for 4-6 years reaching the maximum number of individuals in its neuter population at the end of this period. Resources are subsequently channelled into the production of winged reproductives and, years later, its population declines and the colony dies.

Considering all three development stages of the Isoptera colonies, recognized by Noirot (1969), one can consider the growth of the colony analogous to that of an organism. Thus, in this study we proposed two mathematical models in order to describe the growth of Nasutitermes coxipoensis Holmgren 1910 (Model 1) mounds derived from the Von Bertalanffy (1938) growth curve and a more general formulation (Model 2) for other termite species. Von Bertalanffy developed one of the first models for organic growth, particularly for fishes. 


\section{Material and Methods}

\subsection{Study area}

Mounds sampled in this study were located in a Cerrado area in the Municipality of Itirapina, São Paulo, Brazil ( $22^{\circ} 15^{\prime} \mathrm{S}$ and $47^{\circ} 49^{\prime} \mathrm{W}$, altitude of $\left.765 \mathrm{~m}\right)$. The word "Cerrado" is a Portuguese term meaning "halfclosed" or "dense". In Brazilian terminology it also describes a particular kind of vegetation similar to savannah, although having much broader physiogonomic variation in size and density of trees. That is, the word Cerrado describes a gradient of vegetation comprising "savannah grassland", "low trees and shrub savannah" and "savannah woodland". It is important to point out that the similarities to savannah are only physiogonomic and not floristic. It covers about 2 million $\mathrm{km}^{2}$, or $25 \%$ of the whole Brazilian territory (Ferri, 1976). This supports private farming enterprises where one of the main activities is cattle rearing. Therefore, at times of drought when fire becomes frequent in this locality, the impact of the cattle also becomes more apparent.

The study area is an alluvial plain covered by sandy sediment, with a deep, quartzes' sand soil type (Oliveira and Prado, 1984) and has 12,750 $\mathrm{m}^{2}$.

Mean annual rainfall is $1,425 \mathrm{~mm}$, with the rainy season extending from October to March, when 84\% $(1,199 \mathrm{~mm})$ of the precipitation occurs. The most rainy months are December, January and February, with precipitation average values equal to 288,266 and $262 \mathrm{~mm}$, respectively. The driest months are July and August, with 16 and $19 \mathrm{~mm}$ of precipitation, respectively. The mean annual temperature is $19.7^{\circ} \mathrm{C}$, with January and February being the hottest months with respective mean values of 22.2 and $22.3{ }^{\circ} \mathrm{C}$. The coldest months are June and July with respective mean temperatures of 16.4 and $16.2{ }^{\circ} \mathrm{C}$.

\subsection{Sampling program}

The mean height $(n=3)$ and the mean diameter $(\mathrm{n}=3)$ of ten previously marked mounds, whose initial volumes varied from $3.88 \mathrm{dm}^{3}$ to $19.38 \mathrm{dm}^{3}$, were measured each month for twelve months, from April, 1995 to April, 1996, with the aid of two wood stakes approximately 1 metre in length. Considering that the biggest volume found was equal to $192.46 \mathrm{dm}^{3}$ (Buschini, 1996), this research was been accomplished with small colonies. During the measurements the stakes were vertically placed on each side of the mound and the diameter measured at this distance. To measure the height, a single stake was placed horizontally on the apex of the mound and, with the aid of the metric tape, the distance between the stake and the soil was measured as closely as possible to the base of the mound.

Although some of the mounds present deformations and considering that they are entirely epigean, it was assumed that they have approximately a spherical calotte shape (Figure 1). Thus, the volume of the mounds was evaluated by the formula: $V=\pi / \cdot h\left\{3 r^{2}+h^{2}\right\}$ where $r=d / 2=$ radius and $\mathrm{h}=$ height of the mound (Gieck, 1979).

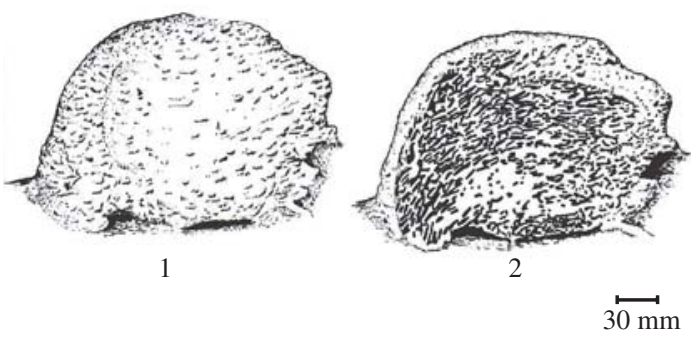

Figure 1. Nests of Nasutitermes coxipoensis. 1) External view; and 2) Internal view.

\section{Results and Discussion}

\subsection{Model 1 for Nasutitermes coxipoensis mounds}

\subsubsection{Growth in height}

The growth in height can be expressed by the differential equation:

$\mathrm{dh}_{\mathrm{k}} / /_{\mathrm{dt}}=\mathrm{k}\left(\mathrm{h}_{\max }-\mathrm{h}_{\mathrm{t}}\right)$

where:

$\mathrm{h}_{\mathrm{t}}=$ height of the mounds in the instant $\mathrm{t} ; \mathrm{k}=$ constant of growth; $\mathrm{h}_{\max }=$ maximum height, that is, the maximum height reached by an adult mound.

Let us suppose that in the instant $\mathrm{t}=0 \Rightarrow \mathrm{h}_{\mathrm{t}}=0$

Then,

$$
\mathrm{dh} /\left(\mathrm{h}_{\max }-\mathrm{h}_{\mathrm{t}}\right)=\mathrm{kdt}
$$

integrating:

$$
\begin{aligned}
& \int \mathrm{dh} /\left(\mathrm{h}_{\max }-\mathrm{h}_{\mathrm{t}}\right)=\int \mathrm{kdt} \\
& -\ln \left(\mathrm{h}_{\max }-\mathrm{h}_{\mathrm{t}}\right)=\mathrm{kt}+\mathrm{c} \text { where } \mathrm{c} \text { is the integrate constant }
\end{aligned}
$$

When $\mathrm{t}=0 \Rightarrow-\ln \left(\mathrm{h}_{\max }\right)=\mathrm{c}$, thus

$$
\begin{aligned}
& -\ln \left(\mathrm{h}_{\text {max }}-\mathrm{h}_{\mathrm{t}}\right)=\mathrm{kt}-\ln \left(\mathrm{h}_{\text {max }}\right) \\
& \ln \left(\mathrm{h}_{\text {max }}\right)-\ln \left(\mathrm{h}_{\text {max }}-\mathrm{h}_{\mathrm{t}}\right)=\mathrm{kt} \\
& \ln \left\{\mathrm{h}_{\text {max }} /\left(\mathrm{h}_{\text {max }}-\mathrm{h}_{\mathrm{t}}\right)\right\}=\mathrm{kt} \\
& \mathrm{h}_{\text {max }} /\left(\mathrm{h}_{\text {max }}-\mathrm{h}_{\mathrm{t}}\right)=\mathrm{e}^{\mathrm{kt}} \\
& \mathrm{h}_{\text {max }}=\mathrm{e}^{\mathrm{kt}}\left(\mathrm{h}_{\text {max }}-\mathrm{h}_{\mathrm{t}}\right) \\
& \mathrm{e}^{-\mathrm{kt}} \mathrm{h}_{\text {max }}=\mathrm{h}_{\text {max }}-\mathrm{h}_{\mathrm{t}} \\
& \mathrm{h}_{\mathrm{t}}=\mathrm{h}_{\text {max }}-\mathrm{e}^{-\mathrm{kt}} \mathrm{h}_{\text {max }} \\
& \mathrm{h}_{\mathrm{t}}=\mathrm{h}_{\text {max }}\left(1-\mathrm{e}^{-\mathrm{kt}}\right)
\end{aligned}
$$


The graph of this function is given in Figure 2. Notice that $h_{\max }$ is an asymptotic value that needs to be determined together with $\mathrm{k}$, through a non-linear regression.

A more flexible model was proposed by Richards (1959) to describe different patterns of organic growth in which the growth rate, in length, is determined by the differential equation:

$$
\mathrm{dD} / \mathrm{dT}=\mathrm{kD} /(1-\mathrm{m})\left[\left(\mathrm{D}_{\max } / \mathrm{D}\right)^{1-\mathrm{m}}-1\right]
$$

where $\mathrm{D}_{\max }$ is the maximum size reached by the organism and $\mathrm{k}$ is a growth constant. The solution of this equation is the growth curve defined by:

$$
D(t)=D_{\max }\left(1-A e^{-k t}\right)^{1 /(1-m)}
$$

If $m=2 / 3$ then we have Von Bertalanffy's model (Brown and Rothery, 1993).

\subsubsection{Growth in volume}

Considering that the nests of Nasutitermes coxipoensis possess the volume of a spherical shape with height $\mathrm{h}$ and radius $\mathrm{r}$, we have:

$$
\mathrm{V}_{\mathrm{t}}=\frac{\pi}{6} \mathrm{~h}_{\mathrm{t}}\left(3 \mathrm{r}_{\mathrm{t}}^{2}+\mathrm{h}_{\mathrm{t}}^{2}\right)
$$

A dispersion diagram of $\mathrm{r} v \mathrm{vs}$. $\mathrm{h}$ of each $N$. coxipoensis mound was drawn. From this graph (Figure 3) we verified that a linear relationship exists, approximately, among them. Then, a model of linear regression $r=\beta_{o}+$ $\beta_{1}$ h was used, and we observed that the slope coefficient of the adjusted straight line is $b_{1}=0.569$.

A test of the hypothesis $\left\{\mathrm{H}_{\mathrm{o}}: \beta_{1}=0.5\right.$ and $\left.\mathrm{H}_{1}: \beta_{1} \neq 0.5\right\}$ was accomplished and it showed that we should accept the null hypothesis $\mathrm{H}_{\mathrm{o}}$, that is, there is strong evidence that $\beta_{1}=0.5$. Thus, firstly, we suppose that:

$$
\mathrm{r}_{\mathrm{t}}=2 \mathrm{~h}_{\mathrm{t}} \text { then, }
$$$$
V_{t}=(\pi / 6) h_{t}\left[\left(3.4 h_{t}^{2}\right)+h_{t}^{2}\right]
$$$$
\mathrm{V}_{\mathrm{t}}=(\pi / 6) \mathrm{h}_{\mathrm{t}} 13 \mathrm{~h}_{\mathrm{t}}^{2}
$$$$
\mathrm{V}_{\mathrm{t}}=\frac{13 \pi}{6} \mathrm{~h}_{\mathrm{t}}^{3}
$$

Replacing (2) in (6) then:

$\mathrm{V}_{\mathrm{t}}=\frac{13 \pi}{6} \cdot \mathrm{h}_{\max }^{3}\left(1-\mathrm{e}^{-\mathrm{kt}}\right)^{3}$

considering. $\mathrm{V}_{\max }=\frac{13 \pi}{6} \mathrm{~h}_{\max }^{3}$

we have:

$\mathrm{V}_{\mathrm{t}}=\mathrm{V}_{\max }\left(1-\mathrm{e}^{-\mathrm{kt}}\right)^{3}$

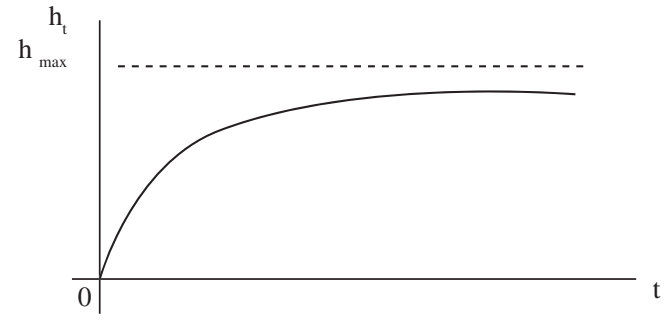

Figure 2. Theoretical growth curve in height $\left(\mathrm{h}_{\mathrm{t}}\right)$ of the mound as a function of time ( $\mathrm{t}$ ), with $\mathrm{h}_{\max }$ being an asymptotic height.

Studying the function : $\mathrm{V}_{\mathrm{t}}=\mathrm{V}_{\max }\left(1-\mathrm{e}^{-\mathrm{kt}}\right)^{3}$

$\mathrm{dV}_{\mathrm{t}} / \mathrm{dt}=3 \mathrm{~V}_{\max }\left(1-\mathrm{e}^{-\mathrm{kt}}\right)^{2} \mathrm{ke}^{-\mathrm{kt}}$

$\mathrm{dV}_{\mathrm{t}} / \mathrm{dt}=3 \mathrm{kV}_{\max } \mathrm{e}^{-\mathrm{kt}}\left(1-\mathrm{e}^{-\mathrm{kt}}\right)^{2}>0$ for $\mathrm{t}>0$,

that is, $V_{t}$ is crescent

$\mathrm{d}^{2} \mathrm{~V}_{\mathrm{t}} / \mathrm{dt}^{2}=3 \mathrm{kV}_{\max }\left\{\begin{array}{l}-\mathrm{ke}^{-\mathrm{kt}}\left(1-\mathrm{e}^{-\mathrm{kt}}\right)^{2}+ \\ \mathrm{e}^{-\mathrm{kt}} 2\left(1-\mathrm{e}^{-\mathrm{kt}}\right) \mathrm{ke}^{-k t}\end{array}\right\}$

$\mathrm{d}^{2} \mathrm{~V}_{\mathrm{t}} / \mathrm{dt}^{2}=3 \mathrm{k}^{2} \mathrm{~V}_{\max } \mathrm{e}^{-\mathrm{kt}}\left(1-\mathrm{e}^{-\mathrm{kt}}\right)\left\{-\left(1-\mathrm{e}^{-\mathrm{kt}}\right)+2 \mathrm{e}^{-\mathrm{kt}}\right\}$

$\mathrm{d}^{2} \mathrm{~V}_{\mathrm{t}} / \mathrm{dt}^{2}=3 \mathrm{k}^{2} \mathrm{~V}_{\max } \mathrm{e}^{-\mathrm{kt}}\left(1-\mathrm{e}^{-\mathrm{kt}}\right)\left(3 \mathrm{e}^{-\mathrm{kt}}-1\right)$

thus, $\mathrm{d}^{2} \mathrm{~V}_{\mathrm{t}} / \mathrm{dt}^{\mathrm{t}}=0 \Leftrightarrow\left(3 \mathrm{e}^{-\mathrm{kt}}-1\right)=0$

$3 \mathrm{e}^{-k \mathrm{t}}=1$

$3=\mathrm{e}^{\mathrm{kt}}$

$\ln 3=\mathrm{kt}$

$\mathrm{t}=\ln 3 / \mathrm{k}$

or $\left(1-\mathrm{e}^{-\mathrm{kt}}\right)=0$

$1=\mathrm{e}^{-\mathrm{kt}}$

$\mathrm{e}^{\mathrm{kt}}=1$

$\mathrm{t}=0$

$\mathrm{d}^{2} \mathrm{~V}_{\mathrm{t}} / \mathrm{dt}^{2}>0 \Leftrightarrow\left(3 \mathrm{e}^{-\mathrm{kt}}-1\right)>0$

$3 \mathrm{e}^{-\mathrm{kt}}>1$

$3>\mathrm{e}^{\mathrm{kt}}$

$\ln 3>\mathrm{kt}$

$\ln 3 / \mathrm{k}>\mathrm{t}$

$\mathrm{d}^{2} \mathrm{~V}_{\mathrm{t}} / \mathrm{dt}^{2}<0 \Leftrightarrow\left(3 \mathrm{e}^{-\mathrm{kt}}-1\right)<0 \Leftrightarrow \mathrm{t}>\ln 3 / \mathrm{k}$

Thus, in $\mathrm{t}=\ln 3 / \mathrm{k}$ we have one inflexion point;

for $\mathrm{t}<\ln 3 / \mathrm{k}, \quad \mathrm{V}_{\mathrm{t}}$ has an upward concavity;

for $\mathrm{t}>\ln 3 / \mathrm{k}, \mathrm{V}_{\mathrm{t}}$ has a downward concavity.

Now, $\lim _{\mathrm{t} \rightarrow \infty} \mathrm{V}_{\mathrm{t}}=\lim _{\mathrm{t} \rightarrow \infty} \mathrm{V}_{\max }\left(1-\mathrm{e}^{-\mathrm{kt}}\right)^{3}=$

$\lim _{\mathrm{t} \rightarrow \infty} \mathrm{V}_{\max }\left(1-1 / \mathrm{e}^{\mathrm{kt}}\right)^{3}=\mathrm{V}_{\max } 1=\mathrm{V}_{\max }$ 
Figure 4 illustrates the behaviour of this function, also asymptotic for $\mathrm{V}_{\max }$.

\subsection{Model 2 for other termite species}

We propose below a more general formulation, without the supposition that $r_{t}=2 h_{t}$.

$$
\mathrm{dr}_{\mathrm{t}} / \mathrm{dt}=\mathrm{k}_{0}\left(\mathrm{r}_{\max }-\mathrm{r}_{\mathrm{t}}\right) \Rightarrow \mathrm{r}_{\mathrm{t}}=\mathrm{r}_{\max }\left(1-\mathrm{e}^{-\mathrm{k}_{0} \mathrm{t}}\right)
$$

and,

$\mathrm{dh}_{\mathrm{t}} / \mathrm{dt}=\mathrm{k}_{1}\left(\mathrm{~h}_{\max }-\mathrm{h}_{\mathrm{t}}\right) \Rightarrow \mathrm{h}_{\mathrm{t}}=\mathrm{h}_{\max }\left(1-\mathrm{e}^{-\mathrm{k}_{\mathrm{t}} \mathrm{t}}\right)$

thus,

$$
\begin{aligned}
& \mathrm{V}_{\mathrm{t}}=\frac{\pi}{6} \mathrm{~h}_{\mathrm{t}}\left(3 \mathrm{r}_{\mathrm{t}}^{2}+\mathrm{h}_{\mathrm{t}}^{2}\right) \\
& \mathrm{V}_{\mathrm{t}}=\frac{\pi}{6} \mathrm{~h}_{\max }\left(1-\mathrm{e}^{-\mathrm{k}_{1} \mathrm{t}}\right)\left[3 \mathrm{r}_{\max }^{2}\left(1-\mathrm{e}^{-\mathrm{k}_{0} \mathrm{t}}\right)^{2}+\mathrm{h}_{\max }^{2}\left(1-\mathrm{e}^{-\mathrm{k}_{1} \mathrm{t}}\right)^{2}\right] \\
& \mathrm{V}_{\mathrm{t}}=\frac{\pi}{2} \mathrm{~h}_{\max } \mathrm{r}_{\text {max }}^{2}\left(1-\mathrm{e}^{-\mathrm{k}_{1} \mathrm{t}}\right)\left(1-\mathrm{e}^{-\mathrm{k}_{0} \mathrm{t}}\right)^{2}+\frac{\pi}{6} \mathrm{~h}_{\max }^{3}\left(1-\mathrm{e}^{-\mathrm{k}_{1} \mathrm{t}}\right)^{3} \\
& \mathrm{dV}_{\mathrm{t}} / \mathrm{dt}=\frac{\pi}{2} \mathrm{~h}_{\max } \mathrm{r}_{\max }^{2}\left[\begin{array}{l}
\mathrm{k}_{1} \mathrm{e}^{-\mathrm{k}_{1} \mathrm{t}}\left(1-\mathrm{e}^{-\mathrm{k}_{0} \mathrm{t}}\right)^{2}+ \\
\left(1-\mathrm{e}^{-\mathrm{k}_{1} \mathrm{t}}\right) 2\left(1-\mathrm{e}^{-\mathrm{k}_{0} \mathrm{t}}\right) \mathrm{k}_{0} \mathrm{e}^{-\mathrm{k}_{0} \mathrm{t}}
\end{array}\right]+ \\
& +\frac{\pi}{6} h_{\max }^{3} 3\left(1-\mathrm{e}^{-k_{1} t}\right)^{2} k_{1} e^{-k_{1} t} \\
& \mathrm{dV}_{\mathrm{t}} / \mathrm{dt}=\frac{\pi}{2} \mathrm{~h}_{\max } \mathrm{r}_{\max }^{2}\left(1-\mathrm{e}^{-\mathrm{k}_{0} \mathrm{t}}\right)\left[\begin{array}{l}
\mathrm{k}_{1} \mathrm{e}^{-\mathrm{k}_{1} \mathrm{t}}\left(1-\mathrm{e}^{-\mathrm{k}_{0} \mathrm{t}}\right)+ \\
2 \mathrm{k}_{0} \mathrm{e}^{-\mathrm{k}_{0} \mathrm{t}}\left(1-\mathrm{e}^{-\mathrm{k}_{1} \mathrm{t}}\right)
\end{array}\right]+ \\
& +\frac{\pi}{2} \mathrm{~h}_{\max }^{3} \mathrm{k}_{1} \mathrm{e}^{-\mathrm{k}_{1} \mathrm{t}}\left(1-\mathrm{e}^{-\mathrm{k}_{1} \mathrm{t}}\right)^{2} \\
& \mathrm{dV}_{\mathrm{t}} / \mathrm{dt}>0 \text { for } \mathrm{t}>0 \Rightarrow \mathrm{V}_{\mathrm{t}} \text { is crescent }
\end{aligned}
$$$$
\lim _{\mathrm{t} \rightarrow \infty} \mathrm{V}_{\mathrm{t}}=\lim _{\mathrm{t} \rightarrow \infty}\left[\begin{array}{l}
\frac{\pi}{2} \mathrm{~h}_{\max } \mathrm{r}_{\max }^{2}\left(1-1 / \mathrm{e}^{\mathrm{k}_{1} \mathrm{t}}\right)\left(1-1 / \mathrm{e}^{\mathrm{k}_{0} \mathrm{t}}\right)^{2}+ \\
\frac{\pi}{6} \mathrm{~h}_{\max }^{3}\left(1-1 / \mathrm{e}^{\mathrm{k}_{1} \mathrm{t}}\right)^{3}
\end{array}\right]=
$$$$
=\frac{\pi}{2} \mathrm{~h}_{\max } \mathrm{r}_{\max }^{2}+\frac{\pi}{6} \mathrm{~h}_{\max }^{3}
$$$$
=\frac{\pi}{6} h_{\max }\left[3 r_{\max }^{2}+h_{\max }^{2}\right]=\mathrm{V}_{\max }
$$

The graph of Vt will not be sketched here because, as it can be observed, the sign of the second derivate $\mathrm{d}^{2} \mathrm{~V} / \mathrm{dt}$ depends on the specifications of $r_{t}$ and $h_{t}$, for each species of termites to be studied.

Faced with these models proposed for $N$. coxipoensis in particular, and for other termites species, it can be thought that the juvenile phase would be equivalent to the initial stages of development of the colony with rates of relative growth $\left\{\left(\mathrm{w}_{2}-\mathrm{w}_{1}\right) /\left(\mathrm{w}_{1}\right)\right\}$ and absolute $\left\{\left(\mathrm{w}_{2}-\mathrm{w}_{1}\right) /\left(\mathrm{t}_{2}-\mathrm{t}_{1}\right)\right\}$ height. The mature phase, for its time, would correspond to the inflexion point with a decrease in the growth rates due to a larger reproductive investment (beginning of the production of winged reproduc-

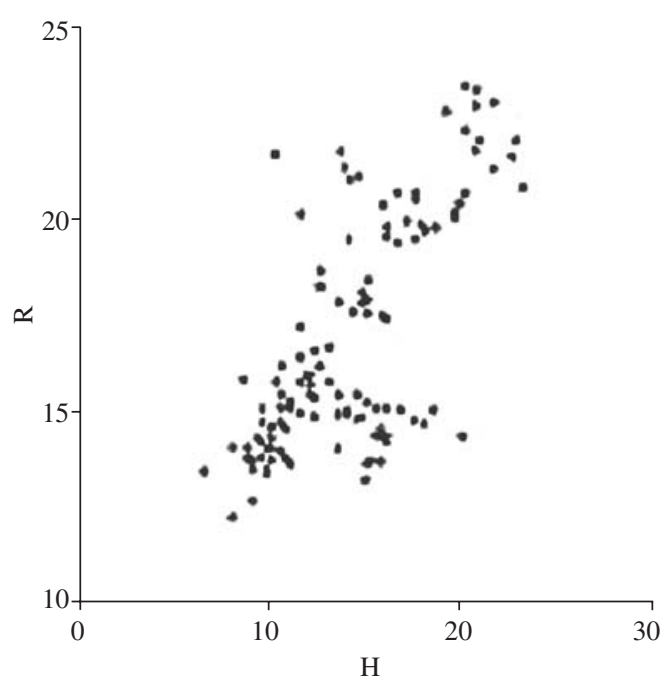

Figure 3. Scatter diagram between the radio (R) and mean height $(\mathrm{H})$ of the mounds.

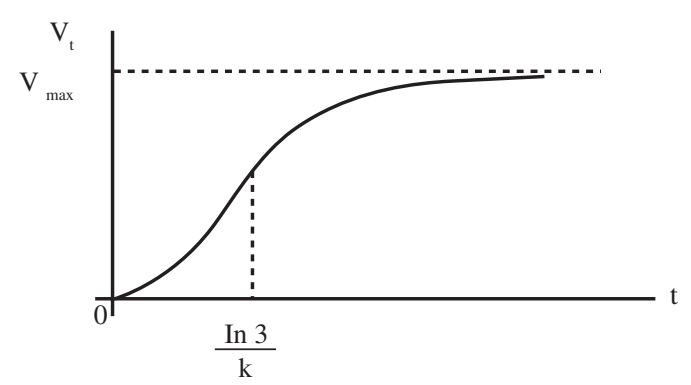

Figure 4. Theoretical growth curve in volume $\left(\mathrm{V}_{\mathrm{t}}\right)$ of the mound as a function of time $(\mathrm{t}) . \mathrm{V}_{\max }$ is the asymptotic volume and $\ln 3 /{ }_{k}$ is the instant when the inflexion point of the curve occurs.

tives in termites). And, finally, the older phase would be the stage during which the colonies reach an asymptotic weight (volume). However, other studies will be necessary to test and to discuss the models presented in this study.

This model can be tested simply by measuring height and diameter of the studied species nests. As mentioned above, the $\mathrm{V}$, graphs have to be sketched for each termite species with their specific values of $r_{t}$ and $h_{t}$. It is important to investigate the relationship between these two variables by initially plotting both variables on the graph and verifying the existence of linearity between them. If $r_{t}=2 h_{t}$, the species in question will present the same growth pattern as $N$. coxipoensis, equivalent to that proposed by Von Bertalanffy (1938). 
Acknowledgements - We would like to thank Prof. Dr. Ana Maria Costa Leonardo for her trust in us. CNPq supplied financial support for the accomplishment of this study.

\section{References}

BANERJEE, B., 1975. Growth of mounds and foraging territories in Odontotermes redemanni (Wasmann) (Isoptera: Termitidae). Insects Sociaux., vol. 22, no 2., p. 207-212.

BROWN, D. and ROTHERY, P., 1993. Models in biology: mathematics, statistics and computing. New York: John Wiley \& Sons.

BUSCHINI, MLT., 1996. Ecologia e biologia de uma espécie de Nasutitermes (Isoptera : Termitidae) no cerrado de ItirapinaSP. Rio Claro : Instituto de Biociências, UNESP. 129 p. [PhD Thesis].

COLLINS, NM., 1981. Populations, age structure and survivorship of colonies of Macrotermes bellicosus (Isoptera: Macrotermitinae). Journal of Animal Ecology, vol. 50, no. 1, p. 293-311.

FERRI, MG., 1976. Ecologia dos cerrados. In Simpósio sobre o cerrado. São Paulo: Itatiaia. p. 15-36.
GIECK, K., 1979. Manual de fórmulas técnicas. São Paulo: Hemus.

LEE, KE. and WOOD, TG., 1971. Termites and soils. London: Academic Press.

NOIROT, C., 1969. Formation of castes in the higher termites. In KRISHNA, K. and WEESNER, FM. (Eds.). Biology of termites. New York: Academic Press. p. 311-350

-, 1970. The nests of termites. In KRISHNA, K. and WEESNER, FM. (Eds.). Biology of termites. New York: Academic Press. p. 73-126

OLIVEIRA, JB. and PRADO, H., 1984. Levantamento pedológico semidetalhado do Estado de São Paulo: quadrícula de São Carlos II. Campinas: Instituto Agronômico. Memorial Descritivo.

RICHARDS, FJ., 1959. A flexible growth function for empirical use. Journal of Experimental Botany. vol. 10, no. 10, p. 290-300.

VON-BERTALANFFY, LV., 1938. A quantitative theory of organic growth (inquiries on growth laws II). Hum. Biol., vol. 10, no 2., p. 181-213. 